\title{
Restitution or a loss to science? Understanding the Importance of Returning Māori Ancestral Remains
}

\author{
Amber Aranui
}

\begin{abstract}
Over the past 20 years, the main focus of repatriation-related publications has been on how the return of human remains impacts on the institutions in which the remains reside. With a few exceptions, discussion has focused on questions concerning whether repatriation of human remains is a loss to science or the public good, and on changes in the way human remains are cared for, treated, displayed, and stored. But what about the effects on the descendant communities from which these remains originate? This article examines the importance of returning Māori ancestral remains back to descendant communities, and the development of the repatriation movement in Aotearoa New Zealand. The ethical consideration relating to research on Māori ancestral remains is explored also to understand how scientific research is viewed and used in the context of Aotearoa New Zealand. It is hoped that by sharing some of the impacts from a Māori perspective, there will be a better understanding of how this affects Indigenous communities globally.
\end{abstract}

Key words: Restitution; Indigenous perspectives; effects on communities; scientific research; ethics.

\section{Titiro whakamuri kia whakairo te huarahi whakamua}

When we learn from our past, we can shape our future. ${ }^{1}$

This whakatauki or Māori proverb reflects the importance of the past. Our whakapapa (genealogy), our taonga (treasures), our tikanga (customs), our stories, and importantly, our ancestors, are all valued aspects of our past which are integral in shaping our future. This is one of the reasons why iwi (nation, tribe or people) Māori are so active in the repatriation movement.

Over the past twenty years, the main focus of repatriation-related publications has been on how the return of human remains has affected the institutions in which the remains reside. The concerns have focused on whether or not repatriation is a loss to science or the public good (e.g. Weiss 2008; Jenkins 2016), and on changes in the way human remains are now cared for, treated, displayed, and stored (e.g. Besterman 1992; Palmer 2003; Fossheim 2013). In this article, by contrast, the focus will be on the effects of repatriation on the descendant communities from which these remains originate. While there are some examples of Indigenous perspectives on the importance of repatriation in the literature on repatriation (e.g. Ayau 1992, 2005; Riding In 1996; Mihesuah 2000; Watkins 2009; Wilson 2009), these are rare by comparison and have only begun to increase in recent years (e.g. Abungu et al. 2018; Aranui 2017; Ayau and Keeler 2017; Lippert 2016). ${ }^{2}$

This article explores the significance of Indigenous epistemological and ontological perspectives through a number of key cultural beliefs and values central to iwi Māori worldviews as well as through the repatriation of Māori ancestral remains. It also examines the importance of collaborative approaches to researching tūpuna ${ }^{3}$ Māori as part of the repatriation process in Aotearoa ${ }^{4}$ New Zealand. The aim of this article is to aid in promoting the normalization of repatriation as part of today's museology. 


\section{Māori cultural beliefs and values}

In order to understand why Māori and many other Indigenous communities feel so strongly about having their ancestral remains returned, it is vital to recognize that we have strong relationships with our dead. Within Te Ao Māori (the Māori world), there are certain beliefs and values that are central elements of the continued connection, respect, and care given to our tūpuna (ancestors), as well as to our people and the whenua (land). These include, but are not limited to, the concepts of tikanga, tapu, mana, whakapapa and wairua.

Tikanga is defined as the set of beliefs associated with practices and procedures to be followed in conducting the affairs of a group or individual in order to act in the correct manner according to the situation (Mead 2003: 12). It is seen as the right or correct way of doing or acting in a given situation.

Tapu is commonly defined as meaning sacred or under spiritual restriction (Williams 2005: 384). It is a concept present in all aspects of Māori culture, and this restriction can be seen as a lore to be observed as long as the tapu is in place. It is important to note that tapu has two aspects to it; as an inherent tapu, which is present in all living things and many types of objects (Mead 2003: 45; Shirres 1982: 20); and, as noted above, as an imposed tapu in the form of a restriction for persons and purposes (Shirres 1982: 46). In the museum context, certain taonga, waka tūpāpaku (burial chest or container) and kōiwi tangata (human remains) require restrictions in their use and handling in order to protect people and are therefore under an imposed restriction due to the power they imbue.

Mana means to be imbued with authority, influence, prestige, and to be effectual and binding (Williams 2005: 172). It is a power all people can have, whether dead or alive. Mana can also be increased and decreased, which becomes apparent in the words of the civil servant and collector of taonga Māori (Māori treasures and antiquities), Thomas E. Donne. In 1908, Donne wrote to Professor Bumpus of the American Museum of Natural History in New York:

I wish you to clearly understand that in relation to these matters as far as I am concerned the utmost privacy must be maintained as I have a great deal to do with the Maoris here and should lose considerable mana were it known that I even indirectly sent Maori bones out of the country (Donne 1908).

Here, Donne is concerned that if Māori in Aotearoa New Zealand knew that he was exchanging or selling tūpuna Māori, then his mana would decrease significantly, and he would no longer have the influence and respect he once had.

Whakapapa is usually translated as genealogy, of people and of things, both tangible and intangible (Barlow 1991:173-5; Te Taura Whiri i te Reo Māori 2008: 1115). In the Māori world, we are connected to everything in some way. In relation to our connection with the dead, regardless of whether or not their names are known, the location in which they are buried indicates in most cases that there is a whakapapa or genealogical connection. With regard to our dead, whakapapa links the past with the present as well as people to the land. If it were not for our ancestors, we would not be here. Therefore, it is important to remember them, hold them in high regard and know how we connect through them to place, whether that be to a larger region or a more specific location, like a marae (meeting house or place).

Wairua is the spiritual essence of all living things (Barlow 1991: 52). From a Māori perspective, 'those who have passed on are often regarded as continuing to be a part of human endeavours, and might be referred to as if still alive' (Durie 2005: 237). With this in mind, one can grasp that when the physical remains of the dead are disturbed or desecrated, then this affects the wairua of that individual, causing restlessness.

It is also important to recognise that urupā or cemeteries and other burial locations are considered tapu and were not treated or viewed in the same way as many Western cemeteries, which are generally maintained in some way and beautified. Some are even made into park-like spaces to be visited, and others are even part of a city as a tourist destination. ${ }^{5}$ In pre-European Aotearoa New Zealand, burial sites were not places to be visited and beautified. They were secret, sacred spaces where the dead were placed to rest peacefully. These spaces were often either hidden in caves and crevices, or buried in unmarked graves so that they could not be desecrated by enemy tribes (Turner 1884: 77; Elder 1932: 157-62; Aranui 2018: 143-4). These views continued well in to the twentieth century, surrounded by the cultural values discussed above. 
By understanding the significance of these five key concepts of tikanga, tapu, mana, whakapapa and wairua, the ontological framework through which iwi Māori engage in the repatriation of ancestral remains can be better appreciated.

\section{The Repatriation Movement in Aotearoa New Zealand and Beyond}

For many of us in Aotearoa New Zealand, the journey of returning our ancestors back to their people has always been part of our culture, and therefore, repatriation in this day and age is not a new process. In the past, when our people died in battle or during journeys away from home, it was important for the remains of the dead to be returned home whenever possible. In the case of battle, it was not always possible to bring back the entire body so it was the head that was often returned so that the family could weep and mourn over them before laying them to rest (Aranui 2018: 141; Robley 1896; Te Awekotuku 2004, 2007).

Repatriation of loved ones back to their hau kāinga or village still continues today. I give the example of my own father, who lived in Wellington for almost thirty years of his life. When he died, his sisters travelled down to Wellington to uplift his body and he was taken back to the tiny village of Pakipaki, about four hours north of Wellington in the Hawke's Bay, where he was born. He was buried with his parents, other ancestors and members of his whānau (family). For me and my sisters, the return of our father's tūpāpaku (body) back to his marae was a normal part of the funerary process. This is a tradition that still lives on in many parts of Aotearoa New Zealand, and demonstrates how repatriation reconnects the living and the dead with the whenua (land).

Another example was the high profile case of James Takamore, who passed away in Christchurch where he and his partner and children lived for over twenty years. His wife had made arrangements for Takamore to be buried in Christchurch (in the South Island). His whānau, who had travelled from the Bay of Plenty (in the North Island), however, believed that his body should be returned home to Kutarere where he was born. ${ }^{6}$ An argument ensued between the families, which caused Takamore's partner to leave the marae where his body lay. According to tikanga, a person's body should not be left unattended, so Takamore's whānau took the opportunity, uplifted him and returned him back to Kutarere, where he was buried in his whānau urupā (cemetery). ${ }^{7}$ The incident was taken to the High Court where the judge ruled that 'members of Mr Takamore's Māori whānau had no entitlement to take his body in the manner that it occurred'. ${ }^{8}$ The decision was appealed twice based on whakapapa (genealogy) and tikanga. However, the Judge decided that the fact that Takamore resided in Christchurch for more than twenty years with his family 'carried greatest weight', giving Takamore's wife's request precedence (Supreme Court 2012: 10)..$^{9}$ This case shows how strongly tikanga around the dead is still important for many iwi and hapū (sub-tribal or extended family group) throughout Aotearoa New Zealand. With more and more Māori living abroad, decisions about final resting places are becoming important. For example, a very good friend of mine, who currently resides in England, has made it clear in her will that, if she dies while still overseas, her body is to be returned to Aotearoa to be buried with her whānau (Aranui 2018: 142). All of these examples show a continuity of cultural practices in relation to funerary practices, particularly relating to returning 'home'.

Aotearoa New Zealand's involvement in the international repatriation movement began with the international exhibition Te Mãori, which toured the United States from 1984 to 1986. This exhibition showcased the fact that taonga, or cultural treasures, were not separate from the people with whom they were associated. This exhibition showed that Māori are a living culture, a people still very much linked to their past (Aranui 2018; Hakiwai 2014; McCarthy 2007; Mead 1984; Te Māori Management Committee 1988). Te Māori was integral in highlighting to the world the importance of the continued connection between the past and the present, as well as in expressing the 'desire for greater Māori control over their own resources', including the return of their tūpuna (Butts 2003: 84). This exhibition can be seen as one of the ways in which Māori have been exercising their tino rangatiratanga (self-determination, autonomy) within the museum world, thus decolonizing those spaces.

International repatriations back to Aotearoa began following this ground-breaking exhibition. One of the most important of those early returns was enacted through the work of 
a Ngāpuhi leader, the late Sir Graham Latimer. Latimer took an active approach to preventing the sale of a Toi moko (tattooed head) from Bonhams auction house in 1988 (Harrison 2002). Taking his grievance to the New Zealand High Court, Latimer was granted legal guardianship over 'Tupuna Māori', as was the legal name given to this ancestor (High Court of New Zealand 1988: 1). Out of his own pocket, Latimer negotiated for the return of Tupuna Māori and travelled to England to uplift him. Tupuna Māori was returned to Aotearoa New Zealand and laid to rest in Northland (Harrison 2002: 139).

Like Latimer, the late Maui Pōmare was a prominent Māori leader who also saw the importance of bringing our tūpuna home. From the 1980s, in his role as chair of the National Museum Council, and in his position as a Winston Churchill Fellowship recipient, Pōmare began to negotiate for the return of Toi moko (Pōmare 1993: 1). He also set the precedent that human remains are not to be categorised as taonga or objects. During this time, he was involved in the return of over 30 tūpuna (Aranui 2018: 162-163). It is because of the work Pōmare started that, in 2003, a formal international repatriation programme was established and funded by the New Zealand Government (Cabinet Office 2003; Karanga Aotearoa Repatriation Programme 2005). The Karanga Aotearoa Repatriation Programme is based at the Museum of New Zealand Te Papa Tongarewa (Te Papa). This repatriation programme, like Te Māori, reflects the continued political decolonization of the museum world at both the national and international level.

\section{Repatriation Developments in Aotearoa}

As active as Aotearoa New Zealand was internationally during the 1980s and 1990s, there was just as much activity at the national level. Following the establishment of the Waitangi Tribunal in 1975, museums that had strong relationships with Māori were proactively returning human remains held in their collections. Māori were also beginning to reclaim control over their cultural heritage including their tūpuna. Ngai Tahu, the largest iwi in the South Island, developed its own kōiwi tangata (human remains) policy (Te Rūnanga o Ngāi Tahu 1993), which was the first human remains policy to be developed in Aotearoa New Zealand. The policy focused on how the iwi would manage the "bones of our tipuna ${ }^{10}$ that all too often are found in eroding burial sites or in museum type collections' (1993: 4). Museums would follow suit from the late 1990s, developing their own policies around the care and return of human remains (Canterbury Museum 1998; Museum of New Zealand Te Papa Tongarewa 2001; Butts 2003; Auckland War Memorial Museum 2008).

Then, in 2003, a major development in New Zealand's involvement occurred. Following meetings between Te Papa, government departments and iwi representatives, a decision was made to fund a programme dedicated to the return of Māori and Moriori ancestral remains from international institutions (Karanga Aotearoa Repatriation Programme 2005: 2). It was funded by the New Zealand government and Te Papa was to be the institution to lead the programme, which was later named the Karanga Aotearoa Repatriation Programme. This development also highlighted the importance of ancestors for Māori who now 'regard koiwi as a taonga protected under the Treaty of Waitangi' (Cabinet Office 2003: 2).

With the momentum increasing on tribal claims regarding breaches of the Treaty of Waitangi $1840,{ }^{11}$ Aotearoa New Zealand's founding document, iwi also began to include the return of their ancestors in these claims. The most prominent example is the return of over 60 tūpuna to Wairau Bar located at the top of the South Island (Waitangi Tribunal 2004). This claim and subsequent repatriation was the result of four generations of struggle to have those ancestors returned following their theft in the 1940s and 50s. The Canterbury Museum's reluctance to return these ancestors was due to the site's potential significance as one of the earliest settlements from Eastern Polynesia (Aranui 2018; Armstrong 2009).

Due to the ongoing domestic repatriation developments in Aotearoa New Zealand, 2018 saw the establishment of the Kaihurahura Whakahoki Kōiwi Tūpuna o Aotearoa (New Zealand Repatriation Research Network). The network is currently made up of 19 museums and one university, which hold the majority of human remains throughout the country. The purpose of the network is to undertake collaborative research and support the return of ancestral remains back to iwi, hapū and other descendant communities. Following the establishment 
of this network and a national survey of museum holdings, the government has also provided a small amount of funding to support museums to return all human remains held throughout the country. This project, called Ngākahu National Repatriation Project, began in September 2019 and is based at Te Papa as part of the museum's outreach team National Services Te Paerangi. This is a major development in Aotearoa New Zealand's repatriation movement and one which will grow as museums begin proactively and collaboratively repatriating human remains contained within their collections.

\section{Emotional Impacts of Repatriation}

In order to understand the importance of returning ancestors home, the emotional impacts of repatriation need to be discussed. In 2012, the Karanga Aotearoa Repatriation Programme returned a number of tūpuna back to Ngāti Tūwharetoa, an iwi located in the central North Island. These tūpuna were returned to six marae ${ }^{12}$ around Lake Taupō. During the tangi or tangihanga (funerary) ceremonies at each of the marae, the women surrounded the boxes that contained their ancestors, weeping, embracing and comforting them. The term tangi not only refers to a funeral, but also means to cry or weep, and tears are an important part of the funeral process. This is expressed in an old Māori proverb, 'Nā te hūpē me ngā roimata ka ea ia te mate', which translates as 'By nose mucus and tears death is avenged' (Mead 2003: 316). This repatriation in particular provides a very good example of how the return of tūpuna back to their whenua and people makes an important impact. During the journey to the various marae, I was told by kaumātua (elders) that for some of them this was the first time in fifty years that they had visited many of the marae along the way. For these men, this occasion represented the reuniting of the people of Ngāti Tūwharetoa as a unified iwi rather than as many connected but separate hapū.

The ancestors were also covered by kākahu or cloaks, which are worn by the living on special occasions and used to embrace the dead during the funeral process. The laying of the kākahu over the dead symbolises the respect given to them and serves to keep them warm. The tears shed during this time are not just about the fact that these tūpuna were stolen and taken away, but also because the occasion brings up memories of a turbulent time in Māori history. These are passed down through generations so as not to be forgotten, which reflects, once again, the importance still held for the past.

In 2013, the Karanga Aotearoa Repatriation Programme also returned a number of ancestral remains back to the isolated community of Waimārama, located on the east coast of the North Island. For the people of Waimārama, this return was particularly important because the person responsible for the removal of the ancestral remains returned at this time was collector Frederick Huth Meinertzhagen, who once lived in and was part of the Waimārama community (Aranui 2013; Grant 1977). It is bad enough that outsiders come in and take remains, but it is even more distressing when a person is accepted into a community and acknowledges their beliefs and values, only to go and steal their ancestors.

Meinertzhagen even mentions in his letters to Julius von Haast at the Canterbury Museum that he needed to be careful as he employed many Māori on his sheep farm and could not afford to 'run counter to their prejudices', stating 'You doubtless know how they respect the bones of their ancestors' (Meinertzhagen 1879: 1). As an interesting side note, the largest single collection of taonga Māori held at the British Museum is from Meinertzhagen, a large proportion of which is from Waimārama (Starzecka et al. 2010: 20). There is the strong desire by the iwi to reconnect with those taonga one day.

These two emotive experiences alone demonstrate the importance of reconnecting the past with the present (descendants with their ancestors), despite having to relive those painful memories. Returning ancestors back to communities helps to close that chapter of the past so that communities can move forward. This is nonetheless an extremely emotional experience, and one that never gets easier.

\section{Ethical Research}

In Aotearoa New Zealand, the government has acknowledged the fact that repatriation and the reburial of their ancestors is important for Māori. Today, when human remains are found 
in archaeological contexts, the first port of call is to contact the police and the local iwi or hapū (Heritage New Zealand 2014). It is the iwi or hapū who decide whether or not remains are to be examined further by scientists or to be reburied. There is some opposition to this within the fields of anthropology and archaeology, and there is the concern internationally that academic study is under threat, 'as the freedom of scholarly and scientific disciplines to define their own goals and chart their own course is gradually replaced by a repatriation agenda' (Jones and Whitaker 2009: 137).

But from a Māori perspective, our ancestors are important to us regardless of how long ago they died, and sending them off to be poked and prodded is seen as incredibly disrespectful. It can be equalled to, for example, me (the author) digging up one of your (the reader) parents or grandparents and taking them away to be studied without asking for your permission. How would that make you feel?

There are, however, instances in which research and repatriation have worked well together. On 16 April 2009, more than 60 tūpuna were reburied at Wairau Bar, 70 years after they were first excavated. Almost all of the ancestors had been held at the Canterbury Museum since their excavation, and two were formally part of the National Museum's (now Te Papa) collections.

The return of these tūpuna was a long awaited event for iwi Rangitāne o Wairau, who had been fighting for the ancestors to be returned and reburied for many years (Armstrong 2009). Their relationship with the Canterbury Museum was not strong or positive after several requests for the return of the remains were denied (Aranui 2018; Armstrong 2009). Rangitāne o Wairau were then forced to include in their Treaty of Waitangi claim the return of their ancestors, which was eventually granted. However, a condition of the return was that the remains were to undergo examination by researchers prior to reburial. This resulted in a memorandum between the iwi, the Museum and the University of Otago, which was approached by the iwi to undertake the research (Aranui 2018: 76; Armstrong 2009). The University of Otago and the Rangitāne o Wairau have developed a close relationship throughout this process, and in my opinion, one which has more than likely changed the way archaeologists work with tribal and community groups throughout Aotearoa New Zealand.

It is important to highlight this relationship, which shows that by working together, there can be benefits for both parties; in this case, by answering questions about who the people were, how they lived, and where they came from. Information about the people who lived there, including what they looked like via facial reconstruction, brought the iwi literally face to face with their past (Hayes et al. 2012). DNA research on the tuppuna from Wairau Bar has uncovered the fact that members of the living community are related to a number of the oldest remains present on the site (Knapp et al. 2012). Isotope research has identified a link back to our Polynesian homeland as several of the ancestors were not born in Aotearoa New Zealand (Kinaston et al. 2013).

The presence of a shell tool not native to Aotearoa New Zealand but to tropical East Polynesia has further linked these people back to their Polynesian origin. Island groups like the Society Islands, Marquesas, Southern Cook Islands and the Austral Islands have also provided evidence of this shell, showing what appears to be the same or similar use during the same time period (Davidson et al. 2011). More is now also known about health and disease, like gout and type 2 diabetes amongst the earliest settlers (Buckley et al. 2010). These are just some examples of the important research that is done in partnership with Rangitāne o Wairau, and an excellent example of how important relationships can be established and maintained with descendant communities.

The ethical considerations of studying human remains in Aotearoa New Zealand are developed in consultation with Māori. Research on Māori ancestral remains, whether found in an archaeological context or held in museum or university collections, cannot be studied unless consent is sought by the descendant community or iwi (Aranui 2018; New Zealand Government 1975). This can prove difficult for students and researchers, as it requires that they engage with Māori, but it ensures that the research benefits not only science but also the descendant community. Research for research sake is no longer an accepted practice. Even as early as the 1980s, Māori were ensuring that their views were heard, as reflected in the words of Dr Philip Houghton (1980: 10): 
It is not possible to study human skeletal material in New Zealand, and indeed throughout Polynesia, without becoming aware that one is dealing with things of the deepest import to traditional belief, where the past and all relating to it is one with, and indivisible from the present.

Houghton was a leading physical anthropologist at a crucial time when Māori were asserting their tino rangatiratanga over their culture, land, language and heritage, including their dead. The attitudes of many of today's researchers and scientists in Aotearoa New Zealand reflect the acceptance and understanding of the importance of free and prior consent (Aranui 2018: 116-24). Certain academics and scientists have commented over the years that repatriation is a loss to science (Weiss 2008); ${ }^{13}$ and a purely political ploy (Jenkins 2011). It is hoped that by sharing some of the impacts of repatriation of human remains from a Māori perspective, as pursued in this article, a better understanding can be gained of how this effects Indigenous communities around the world.

\section{Conclusion}

With repatriation being such an enormous topic for discussion, both in universities and museums, it could be argued that the major impacts have occurred within these institutions themselves rather than among the descendant communities. Māori perspectives have remained constant over time as to how they feel about the dead. Institutions, on the other hand, are becoming more aware that human remains are not just to be viewed as specimens and objects of study and display, but are actual people with descendants who care about them. This is reflected in the developments in Aotearoa New Zealand around the repatriation of ancestral remains, both overseas and domestically, which are now developed and lead by Māori.

Ethical guidelines around the collection and study of the dead have been developed, museum policies have changed, display of the dead is becoming less common, and the sale of Indigenous remains is seen as largely unethical, though it does still occur. In Aotearoa New Zealand, the impacts of these changes can be seen in all academic disciplines that deal with human remains in archaeological and museum collections. Consultation with source communities is mandatory, relationships are extremely important, and scientists who have been interviewed in the course of my recently completed PhD research have indicated that this is a much better way to carry out research. There are, however, still those who do not agree with these changes (Aranui 2018).

Though I now live in post-colonial Aotearoa New Zealand, colonial views still remain in some circumstances. Regardless of this, I still believe that the transformation of views around Māori ancestral remains has moved in a far more positive direction since the nineteenth century. Museums are now normalising repatriation as it becomes part of museum practice in Aotearoa New Zealand, as in other parts of the world such as Australia, the United States and Canada, while the repatriation movement is continuing to gain momentum. In Aotearoa New Zealand, lasting relationships are being formed, communication is becoming more open and honest, and in some instances, scientists and Māori are even working together and the research is now becoming mutually beneficial. An example, perhaps, that the rest of the world may learn from.

Received: 3 September 2019

Finally Accepted: 12 February 2020

\section{Notes}

1 Ministry for Culture and Heritage, 'Te Tai, Treaty Settlement Stories', Te Ara 2018, https:// teara.govt.nz/en/te-tai, accessed 1 June 2019.

2 Edward Halealoha Ayau and Honor Keeler, 'Injustice, Human Rights, and Intellectual Savagery. A Review', H-Soz-Kult 2017. https://www.hsozkult.de/debate/id/ diskussionen-3987, accessed 1 June 2019; Te Herekiekie Herewini, 'A View from Aotearoa New Zealand', H-Soz-Kult 2017. https://www.hsozkult.de/debate/id/diskussionen-4018, accessed 1 June 2019.

3 Tūpuna refers to ancestors (plural). 
4 Aotearoa is the Māori term used for New Zealand. It translates to 'land of the long white cloud'.

5 Visit London, 'London's Cemeteries', 2018. https://www.visitlondon.com/things-to-do/ openspace/cemetery, accessed 11 January 2018.

6 J. McEntyre, 'Body Snatchers', Sunday 17 August 2014. https://www.tvnz.co.nz/shows/ sunday/episodes/s2014-e29, accessed 17 November 2017.

7 McEntyre, 'Body Snatchers'.

8 Natalie Coates, 'What does Takamore mean for Tikanga? -Takamore v Clarke [2012] NZSC 116', Maori Law Review, February 2013. http://maorilawreview.co.nz/2013/02/ what-does-takamore-mean-for-tikanga-takamore-v-clarke-2012-nzsc-116/, accessed 17 November 2017.

9 Coates, 'What does Takamore mean for Tikanga?'.

10 Tipuna and tūpuna both refer to ancestor. Tipuna is the term used by many East Coast and South Island iwi throughout Aotearoa New Zealand.

11 The Treaty of Waitangi is New Zealand's founding document, signed by many Māori chiefs and the British Crown. This document was then used to colonise the country to the detriment of Māori. Unfortunately, the principles were not upheld by the colonial government and, as a result, the Waitangi Tribunal was established in 1975 to deal with the breaches of the Treaty between 1840 and the present day.

12 Marae is the focal point of a Māori settlement or village, consisting of a wide open space and buildings in which the iwi or hapū meet.

13 Robin McKie, 'Scientists Fight Back to Save Ancestral Bone Bank', The Guardian 28 September 2003. http://www.theguardian.com/uk/2003/sep/28/australia.highereducation, accessed 10 October 2018.

\section{References}

Abungu, G., Herewini, T. H., Handler, R and Moses, J. (2018) 'Repatriation: A Conversation', in D. Dean (ed) A Companion to Public History, 231-41, Cornwall: John Wiley and Sons Ltd.

Aranui, A. K. (2013) Kōiwi Tangata Report: Te Taiwhenua o Waimārama. Kōiwi Tangata Provenanced to Waimārama. Unpublished Report: Wellington: Museum of New Zealand Te Papa Tongarewa.

(2017) 'Māori on the Move - Should museums Repatriate Their Dead?', Current World Archaeology, 7 (8) 12-3.

(2018) Te Hokinga Mai O Ngā Tūpuna: Māori Perspectives of Repatriation and the Scientific Research of Ancestral Remains. Unpublished PhD Thesis: Victoria University of Wellington.

Armstrong, D. (2009) Wairau Bar Koiwi Tipuna and Taonga. Unpublished Report:

Commissioned by Te Rangitāne o Wairau.

Auckland War Memorial Museum (2008) Governance Policy: Human Remains. 
Ayau, E. H. (1992) 'Restoring the Ancestral Foundation of Native Hawaiians: Implementation of the Native American Graves Protection and Repatriation Act', Arizona State Law Journal, 24 193-216.

(2005) 'Honour thy Ancestor's Possessions', Public Archaeology, 4: 193-7.

Barlow, C. (1991) Tikanga Whakaaro: Key Concepts in Māori Culture, Melbourne: Oxford University Press.

Besterman T. (1992) 'Disposals from Museum Collections: Ethics and Practices', Museum Management and Curatorship, 11 29-44.

Buckley, H., Tayles, N., Halcrow, S. E., Robb, K. and Fyfe, R. (2010) 'The People of Wairau Bar: a Re-examination', Journal of Pacific Archaeology, 1 (1) 1-20.

Butts, D. (2003) Māori and Museums: The Politics of Indigenous Recognition. Unpublished PhD Thesis: Massey University, Palmerston North.

Cabinet Office (2003) Cabinet Policy Minute POL(03)118: Government Policy on the Repatriation of Kōiwi Tangata Māori (Māori Human Remains), 13 May. Wellington: Cabinet Office.

Canterbury Museum (1998) Kōiwi Tangata Policy.

Davidson, J., Findlater, A., Fyfe, R., MacDonald, J. and Marshall. B. (2011) 'Connections With Hawaiki: The Evidence of a Shell Tool from Wairau Bar, Marlborough, New Zealand', Journal of Pacific Archaeology, 2 (2) 93-102.

Donne, T. E. (1908) Letter to Prof. Bumpus, American Museum of Natural History. American Museum of Natural History Archives, T. E. Donne Letters (Central Archives Folder \#132 a-b).

Durie, M. (2005) Ngā Tai Matatū: Tides of Māori Endurance, Melbourne: Oxford University Press.

Elder, J. R. (1932) Letters and Journals of Samuel Marsden, London: Penguin Books.

Fossheim, H (ed.) (2013) More Than Just Bones: Ethics and Research on Human Remains, Norway: Forskningsetiske Komiteer.

Grant, S. (1977) Waimārama, Dunmore Press Ltd: Palmerston North.

Hakiwai, A. T. (2014) He Mana Taonga, He Mana Tangata: Māori Taonga and the Politics of Māori Tribal Identity and Development. Unpublished PhD Thesis: Victoria University of Wellington.

Harrison, N. (2002) Sir Graham Latimer, a Biography, Wellington: Huia Publishers.

Hayes, S., Buckley, H., and Bradley, R. (2012) 'Approximating the Face of 'Aunty': A Question of Likeness', Journal of Archaeological Method and Theory, 19 306-21.

Heritage New Zealand (2014) Kōiwi Tangata Human Remains, Heritage New Zealand Pouhere Taonga Archaeological Guidelines Series.

High Court of New Zealand (1988) CH1988 T No. 4062: In the Matter of the Estate of Tupuna Maori late of New Zealand, Warrior, Deceased, High Court of Justice Chancery Division.

Houghton, P. (1980) The First New Zealanders, Auckland: Hodder \& Stoughton. 
Jenkins, T. (2011) Contesting Human Remains in Museum Collections: The Crisis of Cultural Authority, London: Routledge.

(2016) Keeping their Marbles: How the Treasures of the Past End Up in Museums... and Why They Should Stay There, London: Oxford Press.

Jones, D. G. and Whitaker, M. I. (2009) Speaking for the Dead: The Human Body in Biology and Medicine, Surrey: Ashgate Publishing Limited.

Karanga Aotearoa Repatriation Programme (2005) Background to the Karanga Aotearoa Programme, Wellington: Museum of New Zealand Te Papa Tongarewa.

Kinaston, R. L., Walter, R. K., Jacomb, C., Brookes, E., Tayles, N. and Halcrow, S. E. (2013) 'The First New Zealanders: Patterns of Diet and Mobility Revealed Through Isotope Analysis', PLOS ONE, 8 (5) e64580.

Knapp, M., Horsburg, A., Prost, S., Stanton, J. and Buckley, H. (2012) 'Complete Mitochondrial DNA Genome Sequences from the First New Zealanders', Proceedings of the National Academy of Sciences of the United States of America, 109 (45) 18350-4.

Lippert, D. (2016) 'Repatriation and the Limits of Genetic Identity', in A. Walker, B. Egan, and G. Nicolas, G. (eds) DNA and Indigeneity: The Changing Role of Genetics in Indigenous Rights, Tribal Belonging, and Repatriation, 248, Symposium Proceedings. Intellectual Property Issues in Cultural Heritage (IPinCH) Project, Simon Fraser University, Burnaby, BC.

McCarthy, C. (2007) Exhibiting Māori: A History of Colonial Cultures on Display, Wellington: Te Papa Press.

Mead, H. M. (ed) (1984) Te Maori: Maori Art from New Zealand Collections, New York: Heinemann, American Federation of Arts.

(2003) Tikanga Māori: Living by Māori Values, Wellington: Huia Publishers.

Meinertzhagen, F. H. (1879) Letter to Julian von Haast, 17 November. Alexander Turnbull Library, MS-Copy-Micro-0717-09, Folder 119.

Mihesuah, D. A. (ed) (2000) Repatriation Reader: Who Owns Native American Remains?, Lincoln: University of Nebraska Press.

Museum of New Zealand Te Papa Tongarewa (2001) Kōiwi Tangata Policy, Version One.

New Zealand Government (1975) Historic Places Amendment Act 1975.

Palmer, N. (2003) The Report of the Working Group on Human Remains. Unpublished Report. https://plone.unige.ch/art-adr/cases-affaires/17-tasmanian-human-remains2013-tasmanian-aboriginal-centre-and-natural-history-museum-london/workinggroup-on-human-remains-report-14-november-2003

Pōmare, M. (1993) Memorandum: Tattooed Heads. Karanga Aotearoa Repatriation Programme, Māui Pōmare File.

Robley, H. G. (1896) Moko or Māori Tattooing, London: Chapman and Hall Limited.

Riding In, J. (1996) 'Repatriation: A Pawnee’s Perspective', American Indian Quarterly, 20 (2) 238-50.

Shirres, M. P. (1982) 'Tapu’, Journal of the Polynesian Society, 91 (9) 29-52. 
Starzecka, D. C., Neich, R. and Pendergrast, M. (2010) Taonga Māori in the British Museum, Wellington: Te Papa Press.

Supreme Court (2012) Takamore v Clarke SC 131/2011. NZSC, 116.

Te Awekotuku, N. (2004) 'He Maimai Aroha: A Disgusting Traffic for Collectors: The Colonial Trade of Preserved Heads in Aotearoa, New Zealand', in A. Kiendl (ed) Obsession, Compulsion, Collection: On Objects, Display Culture, and Interpretation, 77-91, Toronto: Baff Centre Press.

(2007) Mau Moko, Auckland: Penguin Books.

Te Māori Management Committee (1988) Te Māori: He Tukunga Korero, a Report, Wellington: Department of Māori Affairs.

Te Rūnanga o Ngāi Tahu (1993) Te Wawata o Ngāi Tahu a pa ana ki Ngā Tāoka Koiwi o Ngā Tupuna: The Policy of Ngāi Tahu Concerning the Human Remains of our Ancestors. Unpublished Document, Te Rūnanga o Ngāi Tahu.

Te Taura Whiri i te Reo Māori (2008) He Pātaka Kupu: te kai a te rangatira, North Shore: Raupo.

Turner, W. (1884) Report of the Scientific Results of the Voyage of H.M.S. Challenger during the years 1873-76, under the command of Captain George S. Nares, R.N.F.R.S. and the late Captain Frank Tourle Thompson, R.N. Zoology Part XXIX, Report on the Human Skeletons collected by the H.M.S. Challenger during the years 1837-1876, Edinburgh: Adam and Charles Black.

Waitangi Tribunal (2004) Deed of Settlement Schedule Documents: Rangitāne o Wairau and Rangitāne o Wairau Settlement Trust. Unpublished Document. https://www. govt.nz/treaty-settlement-documents/rangitane-o-wairau/

Watkins, J. (2009) Sacred Sites and Repatriation, Philadelphia: Chelsea House Publishers.

Weiss, E. (2008) Reburying the Past: The effects of Repatriation and Reburial on the Scientific Inquiry, New York: Nova Science Publishers Inc.

Williams, H. W. (2005) Dictionary of the Māori Language, Wellington: Legislation Direct.

Wilson, C. (2009) 'Implications and Challenges of Repatriating and Reburying Ngarrindjeri Old People from the 'Edinburgh Collections', Museum International, May 37-40.

\section{Biography}

Amber Aranui is a researcher for the Karanga Aotearoa Repatriation Programme at the Museum of New Zealand Te Papa Tongarewa, where she undertakes provenance research to aid in the return of Māori and Moriori ancestral remains back to their descendant communities. Amber has a background in Anthropology and Archaeology and has recently completed her PhD at Victoria University of Wellington, focusing on Māori perspectives on repatriation and scientific research of Māori ancestral remains. She is of Ngāti Kahungunu and Ngāti Tūwharetoa descent, and is dedicated to working with iwi Māori as well as other Indigenous peoples throughout the world. 